\title{
Kolaborasi Berbagai Pihak Dalam Peningkatan Jumlah Ruang Terbuka Hijau (RTH)
}

\author{
Deden Achmad \\ Universitas Muhammadiyah Makassar
}

Ruang terbuka hijau kota merupakan pertemuan antara sistem alam dan manusia dalam lingkungan perkotaan (urban). Kawasan perkotaan yang berkelanjutan ditandai oleh interaksi dan hubungan timbal balik yang seimbang antara manusia dan alam yang hidup berdampingan di dalamnya. Pada kasus lingkungan perkotaan berpenduduk padat, keseimbangan tersebut mengalami gangguan akibat berkurangnya ruang terbuka hijau. Pentingnya keberadaan ruang terbuka hijau kota, terutama dalam lingkungan tempat tinggal, telah dibuktikan dalam beberapa penelitian 1 Ruang terbuka hijau kota merupakan komponen penting yang mempengaruhi kualitas kehidupan manusia, baik secara ekologis maupun sosial-psikologis. Namun demikian, saat ini proporsinya semakin berkurang sebagai dampak dari tingginya kepadatan penduduk akibat pertumbuhan populasi manusia yang semakin meningkat1. Peningkatan populasi tersebut secara tidak langsung diikuti oleh peningkatan kebutuhan akan konsumsi energi dan lahan bermukim.

Konsep mengenai pembangunan berkelanjutan merupakan bentuk representasi strategi dalam menghadapi permasalahan yang ditimbulkan oleh karakter kawasan perkotaan2 .Pembangunan berkelanjutan (Sustainable Development) adalah pembangunan yang berlangsung selama waktu yang lama. Gagasan pembangunan daerah berkelanjutan (Sustainable Regional Development) mengacu pada integrasi prinsip-prinsip pembangunan berkelanjutan ke dalam praktek pembangunan daerah . Kedua, indikator saat ini dianggap sebagai 
memiliki peran yang semakin penting dalam pembangunan berkelanjutan atau pembangunan daerah yang berkelanjutan dan dapat memberikan bimbingan penting bagi pengambilan keputusan dalam berbagai cara. konsep kebijakan kualitatif, yang membutuhkan operasionalisasi kuantitatif memberikan kontribusi yang signifikan terhadap realisasi pembangunan daerah secara berkelanjutan3.

Berdasarkan konsep ini, salah satu upaya yang dapat dilakukan adalah menjaga dan mengembalikan ruang terbuka hijau ke dalam lingkungan perkotaan dengan berbentuk sistem, sehingga dapat berperan optimal dari sisi agama, ekologi, sosial dan ekonomi. Pembentukan sistem ruang terbuka hijau kota merupakan respon terhadap kebutuhan ruang terbuka hijau suatu wilayah perkotaan, yang meliputi kebutuhan dari aspek ekologis, sosial, dan ekonomi wilayah tersebut. 


\section{DAFTAR PUSTAKA}

Nahruddin,Z. (2018). Collaborative Governance dalam Pengelolaan Lingkungan . INA- Rxiv,Open Science Framework.

J. Wu, Toward a Landscape Ecology of Cities:Beyond Buildings, Trees, and Urban Forests. Dalam Ecology, Planning, and Management of Urban Forests International Perspectives, Ed.Margaret M. Carreiro, Yong-Chang Song and Jianguo Wu. Springer

Science+Business Media, LLC, New York, 2008 Kementrian ekerjaan Umum,Program Pengembangan Kota Hijau (P2KH) Panduan Pelaksanaan, 2011.

Moersidik, Pembangunan Kota Hijau Berkelanjutan (Green City). Kick Off P2KH Wilayah timur Direktorat Jenderal Penataan Ruang Kementerian Pekerjaan Umum, 2012. 